\title{
Namnožitev smrekovega zavijača (Epinotia tedella) v Sloveniji leta 2016
}

\section{Andreja KAVČIČ ${ }^{* 1}$, Barbara PIŠKUR ${ }^{1}$, Nikica OGRIS ${ }^{1}$ S̆pela JAGODIC $^{1}$, Gorazd MLIN- ŠEK ${ }^{2}$, Tomaž BRICMAN ${ }^{2}$, Barbara SLABANJA ${ }^{3}$, Viktor MIKLAVČIČ ${ }^{3}$, Vida PAPLER- LAMPE $^{4}$, Robert KLANČAR ${ }^{4}$, Marijan DENŠA ${ }^{5}$, John VUGRINEC ${ }^{5}$}

\section{Uvod}

Konec oktobra 2016 smo na Koroškem v okolici Dravograda (GGO Slovenj Gradec) opazili poškodbe na navadni smreki (Picea abies (L.) H. Karst.), ki v preteklosti na tem območju še niso bile opažene. V tednih, ki so sledili, so bile enake spremembe na smreki opažene še na Pohorju in tudi v drugih delih Slovenije, v okolici Vrhnike (GGO Ljubljana), na Pokljuki in Jelovici (GGO Bled) ter na Smrekovcu (OE Nazarje).

Na prizadetih smrekah se predvsem na starejših delih vej in poganjkov pojavlja obsežno rumenenje, rjavenje in sušenje iglic (slika 1). Opazni so skupki porumenelih, rjavih in suhih iglic, ki so med seboj povezane z zelo nežnimi svilnatimi nitkami bele barve, suhe iglice pa odpadajo (slika 2). Na posameznih iglicah so vidne poškodbe zaradi grizenja in rumeno rjavi madeži. Na nekaterih iglicah je ovalna luknjica, ki je vidna že s prostim očesom in vodi v rov v notranjosti iglice (slika 3). Med poškodovanimi iglicami so velike količine iztrebkov v obliki majhnih sivo zelenih kroglic in posamezne ličinke (slika 4). Ličinke so dolge približno $8 \mathrm{~mm}$, svetlo zelene barve in imajo črno glavo. Nekatere ličinke so nežne roza barve in imajo na hrbtni strani vzdolž telesa dve tanki progi temnejše roza barve.

Vodje odsekov za gojenje in varstvo gozdov z območnih enot Zavoda za gozdove Slovenije (ZGS), kjer so bile poškodbe opažene, so o pojavu obvestili Gozdarski inštitut Slovenije (GIS) in v Laboratorij za varstvo gozdov (LVG) posredovali vzorce (veje poškodovanih smrek s simptomi in znaki) za določitev škodljivca. V Laboratorij za varstvo gozdov GIS so bili dostavljeni štirje vzorci, ki so bili analizirali po veljavnih laboratorijskih postopkih. V vzorcih iz okolice Dravograda, s Pokljuke in s Smrekovca je bil kot glavni povzročitelj poškodb na smreki določen smrekov zavijač, Epinotia tedella (Clerck, 1795), v vzorcu iz okolice Vrhnike pa je bilo povzročiteljev poškodb več - v vzorcu so bili poleg smrekovega zavijača prisotni tudi prave listne uši (Hemiptera: Ahididae) in kaparji (Hemiptera: Diaspididae in Coccidae) ter gliva Rhizosphaera pini (Corda) Maubl., ki povzroča rjavenje smrekovih iglic. Rezultati analiz vzorcev so dostopni na spletnem portalu za varstvo gozdov v Sloveniji (www.zdravgozd.si/pdp porocila index.aspx): Poročilo o preskusu št.: LVG 2016184, Poročilo o preskusu št.: LVG 2016-185, Poročilo o preskusu št.: LVG 2016-188 in Poročilo o preskusu št.: LVG 2016-194. Morfološko določitev smrekovega zavijača (Epinotia tedella) smo potrdili z dodatno genetsko analizo, ki je vključevala izolacijo DNA iz gosenice, pomnoževanje dela regije za zapis citokrom oksidaze I (COI) in primerjavo $\mathrm{z}$ javno dostopno bazo podatkov
GenBank. Nukleotidno zaporedje se je 99-odstotno ujemalo z zaporedjem KX049150, ki predstavlja nukleotidno zaporedje dela regije COI iz vzorca Epinotia tedella z Norveške (Mutanen in sod., 2016). Nukleotidno zaporedje iz vzorca, nabranega letos v Sloveniji (Dravograd), smo shranili v zbirko GenBank pod identifikacijsko številko KY312114.

\section{Opis vrste}

Epinotia tedella je metulj iz družine listnih zavijačev (Lepidoptera, Tortricidae). Vrsta je prisotna v večini evropskih držav, splošno razširjena in pogosta pa je predvsem v severni in srednji Evropi. Odrasli metulji so majhni, čez krila merijo približno $13 \mathrm{~mm}$, in so rjavi do črnorjavi. Na sprednjem paru kril imajo značilen vzorec iz belih in rjavih prog, ki pa zaradi velike barvne variabilnosti, ki je značilna za to vrsto, lahko tudi manjka (slika 5).

Smrekov zavijač ima praviloma eno generacijo na leto, vendar se lahko v toplejših letih razvijeta tudi dve. Odrasli metulji letajo od aprila do junija, v primeru dveh generacij tudi avgusta. Aktivni so podnevi, rojenje pa je najbolj intenzivno v večernem mraku. Najbolj jim ustrezajo temperature med 13 in $20^{\circ} \mathrm{C}$. Po oploditvi samica jajčeca odloži na iglice smreke (Picea sp.), in sicer po eno jajčece na spodnjo stran posamezne iglice, praviloma v notranjem delu krošnje. Za odlaganje jajčec prednostno izbira debelejše iglice na gosteje olistanih poganjkih smrekovih dreves. V bolj odprtih sestojih odlagajo jajčeca predvsem v spodnjih delih krošnje, v bolj gostih sestojih pa samice odlagajo jajčeca tudi v zgornjih delih.

Jajčeca so rahlo ovalna, velika $0,5 \times 0,6 \mathrm{~mm}$, sprva rumenkasto bela, kasneje pa potemnijo in postanejo rdečkasto rjava ali sivkasta. Embrionalni razvoj v laboratorijskih razmerah traja $10 \mathrm{dni}$. Iz jajčec se izležejo gosenice, ki ob koncu razvoja v dolžino merijo približno 9 mm. Imajo črno glavo ter črn hrbtni ščitek prvega člena oprsja (pronotum). Preostalo telo je bodisi rumenkasto rjavo $\mathrm{z}$ dvema vzdolžnima rdečerjavima progama na hrbtni strani bodisi zelenkaste barve s svetlejšimi ali temnejšimi vzdolžnimi progami na hrbtni strani. Mlajše gosenice na hrbtni strani nimajo vzdolžnih prog. Za gosenice E. tedella so značilni tudi 3 pari rjavih do črnih nog na oprsju ter pet parov nepravih nog (panožice) na zadku. Na površini gosenice izraščajo ščetine, ki so pritrjene na drobne hitinske ploščice rjavkaste barve na površini integumenta. Gosenice, ki se izležejo iz jajčeca, se skozi povrhnjico iglice pregrizejo v njeno notranjost, kjer se prehranjujejo $s$ tkivom iglice (parenhim) v smeri od osnove proti vrhu in jo izvotlijo. Pri tem se ob vhodni 
odprtini v iglico kopičijo iztrebki v obliki rjavkastih kroglic. Posamezna gosenica v času svojega razvoja izvotli 12-22 sosednjih iglic, po nekaterih podatkih tudi več deset. Gosenice izločajo zelo tanke, svilnate belkaste nitke, $\mathrm{s}$ katerimi zapredejo izvotlene iglice v nekakšne snope. $\mathrm{V}$ pajčevinastem zapredku, ki povezuje poškodovane iglice, so prisotne tudi večje količine iztrebkov, ki jih izločajo gosenice. Poškodovane iglice postanejo prosojne, porumenijo in porjavijo ter se na koncu posušijo. Ker so $\mathrm{z}$ nitkami povezane $\mathrm{v}$ skupke in pritrjene na poganjke, odmrle iglice ne odpadejo takoj, ampak posušene ostanejo na drevesu še nekaj časa. V kasnejši fazi razvoja gosenice zapustijo rov v notranjosti iglice, si spredejo svilnat zapredek neposredno ob glavnem poganjku in obžirajo iglice od zunaj. Prednostno obžirajo tanjše iglice. Jeseni, med oktobrom in decembrom, ko dnevne temperature padejo pod $5{ }^{\circ} \mathrm{C}$, gosenice preidejo v stanje mirovanja. Spustijo se v tla, kjer v sivkastem zapredku dolžine 6-7 mm prezimijo zakopane med opadom iz iglic. V raziskavi, ki je bila opravljena na Poljskem, so ugotovili, da določen delež gosenic prezimuje tudi $\mathrm{v}$ krošnji. Naslednjo pomlad aprila ali maja se gosenice v svilnatem kokonu zabubijo. Buba je rumenkasto rjava in dolga 3-6 mm. Po 5-6 tednih se iz bub izleže nova generacija metuljev.

\section{Gostiteljske rastline}

Razvoj smrekovega zavijača je vezan na smreke ( $P i$ cea spp.). V glavnem jo to navadna smreka (Picea abies (L.) H. Karst.), vendar se vrsta pojavlja tudi na drugem drevju, na primer na sitki ( $P$. sitchensis (Bong.) Carr.) in na alkoški smreki ( $P$. alcoquiana Veitch ex Lindl. carrière). Kot gostiteljske rastline, ki omogočajo razvoj osebkov E. tedella, so primerna drevesa vseh starosti. Odrasle gosenice so bile najdene tudi na evropskem macesnu (Larix decidua Mill.), duglaziji (Pseudotsuga menziesii (Mirb.) Franco) in na rdečem boru (Pinus sylvestris L.), vendar na teh gostiteljskih rastlinah vrsta ne more uspešno zaključiti svojega razvoja.

\section{Poškodbe}

Poškodbe zaradi smrekovega zavijača se pojavljajo v krošnji drevesa. Na smrekah v fazi debeljaka so poškodbe omejene večinoma na spodnji del krošnje, na smrekah v fazi drogovnjaka pa se poškodbe pojavljajo tudi v zgornjih delih krošnje. Na mladih drevesih je prizadeta celotna krošnja. Prve poškodbe se začnejo pojavljati v poletnem času in so omejene na notranji del krošnje, zaradi česar je prisotnost škodljivca sprva težko zaznati. Kasneje, ko se z razvojem gosenic intenziteta obžiranja povečuje, se simptomi in znaki, ki kažejo na prisotnost smrekovega zavijača, razširijo in se pojavljajo tudi v zunanjih delih krošnje. V primeru močnih namnožitev se poleg poškodovanosti iglic in defoliacije v vseh delih krošnje pojavi tudi obsežna prepredenost iglic in vej s svilnatimi nitkami. Močno prizadeta drevesa oslabijo, zaradi česar se $\mathrm{v}$ prihodnjih letih zmanjša prirast lesa, poveča pa se dovzetnost za škodljivce in bolezni. Obsežnejše poškodbe lahko vodijo v odmiranje spodnjih vej prizadetih dreves, $\mathrm{v}$ mladih sestojih pa $\mathrm{v}$ primeru večjih izbruhov lahko pride tudi do odmiranja celih dreves. V primeru nekaterih namnožitev smrekovega zavi- jača so bile obsežne poškodbe drevja posledica sočasnega vpliva tudi drugih defoliatorjev na smreki, med drugim metuljev iz družine zapredkarjev (Lepidoptera, Yponomeutidae: Argyresthia sp.) ter rastlinskih os listaric (Hymenoptera, Tenthredinidae: Pachynematus sp.) in zapredkaric (Hymenoptera, Pamphiliidae: Cephalcia sp.).

Obsežne namnožitve smrekovega zavijača se pojavljajo tam, kjer so gostiteljska drevesa prizadeta zaradi različnih biotskih in abiotskih dejavnikov. Še posebej problematična so območja, kjer so tla revna s hranili, preskrbljenost gostiteljskih rastlin z vodo pa je slaba. V literaturi se kot mejna vrednost za kritično namnožitev E. tedella navaja 60 do 70 gosenic na 1 metru veje. Izbruhi so kratkotrajni in večinoma ne trajajo dlje kot 2-3 leta, saj se v tem času namnožijo tudi biotični dejavniki, kot so zajedavci in plenilci E. tedella, ki negativno vplivajo na številčnost osebkov in s tem zmanjšanje populacije smrekovega zavijača.

Prva poročila o izbruhih smrekovega zavijača so iz let 1939-1940 na Češkem in Poljskem. Od takrat so bile obsežnejše namnožitve zabeležene še v Avstriji, v Nemčiji, na Danskem in v Belgiji. V vseh primerih so se izbruhi pojavljali lokalno in povsem naključno, bili so kratkotrajni, njihov vpliv na gozdni sestoj pa je bil zanemarljiv. Po literaturi sodeč se v preteklosti na ozemlju Slovenije namnožitve smrekovega zavijača niso pojavljale.

\section{Zajedavci in plenilci}

V naravi je številčnost osebkov E. tedella regulirana $\mathrm{z}$ abiotičnimi in biotičnimi dejavniki, ki vplivajo na preživetje osebkov na različnih stopnjah njihovega razvoja. Medtem ko je od abiotičnih dejavnikov za preživetje osebkov E. tedella ključna temperatura, so med biotičnimi dejavniki to zajedavci in plenilci. Zaradi vpliva teh biotičnih dejavnikov je smrtnost osebkov E. tedella visoka, kar je ključno za relativno hiter upad številčnosti populacije v primeru obsežnih namnožitev in kratek rok trajanja izbruhov. V literaturi so kot biotični dejavniki, ki so ključni za smrtnost osebkov smrekovega zavijača, omenjene parazitoidne ose vrst Trichogramma evanescens Westwood 1833 in T. embryophagum (Hartig 1838) (Hymenoptera, Trichogrammatidae), ki so parazitoidi na jajčecih smrekovega zavijača, muhe goseničarke vrste Lissonota dubia Holmgren 1856 (Diptera, Tachinidae) ter parazitoidne ose vrst Apanteles tedellae Nixon 1961 (Hymenoptera, Braconidae) in Pimplopterus dubius Hgn. (Hymenoptera, Ischneumonidae), ki so parazitoidi na ličinkah, gliva Isaria farinosa (Holmsk.) Fr. (Hypocreales, Cordycipitaceae), ki povzroča glivične bolezni na prezimovajočih gosenicah, ter hrošči Athous subfuscus (O. F. Muller 1764) iz družine pokalic (Coleoptera, Elateridae), katerih ličinke plenijo gosenice in bube smrekovega zavijača po prezimovanju.

\section{Ukrepi}

Smrekov zavijač v primeru zelo obsežnih namnožitev lahko povzroči znatne poškodbe na prizadetih drevesih in v šestdesetih letih prejšnjega stoletja so v Nemčiji in na Češkoslovaškem za uničevanje $E$. tedella uporabljali kemična sredstva. Vendar pa kljub izbruhom, ki so se v preteklem stoletju pojavljali po Evropi, ni poročil o 
večji gospodarski škodi v gozdovih zaradi te vrste. Eden od glavnih razlogov je ta, da gosenice smrekovega zavijača iglice obžirajo poleti in jeseni in obžirajo $\mathrm{v}$ glavnem le starejše iglice, tako da ne pride do poškodb brstov smreke. Poleg tega se izbruhi praviloma pojavljajo le lokalno in so kratkotrajni. Vpliv škodljivca na nivoju gozdnega sestoja je zato minimalen in poseben nadzor ali ukrepi proti smrekovemu zavijaču se ne izvajajo. Izkušnje v primeru nekaterih večjih izbruhov tudi kažejo, da je kljub obsežnim poškodbam na drevju zaradi E. tedella v naslednji sezoni prišlo do popolne regeneracije prizadetih dreves.

\section{Možne zamenjave}

Od daleč lahko simptome napada smrekovega zavijača zamenjamo s simptomi bolezni rjavenja smrekovih iglic, ki ga povzroča gliva Rhizosphaera pini (Corda) Maubl. ali druge vrste iz tega rodu, npr. R. kalkhoffii Bubák, R. macrospora Gourb. \& M. Morelet., R. oudemansii Maubl. Razlikovanje med slednjimi je možno samo na podlagi natančne morfološke analize v laboratoriju. Rjavenje smrekovih iglic se pojavlja v dveh oblikah, in sicer kot pravi parazit in kot parazit šibkosti. Najpogosteje se pojavlja na poškodovanih smrekah zaradi suše. Gliva poškoduje iglice enoletnih poganjkov, kjer se $\mathrm{v}$ poznem poletju ali jeseni vidne rumene pegice, ki se širijo, dokler se iglica končno ne obarva svetlorjavo ali svetlordeče (slika 6; Maček, 2008). Odmrle iglice ostanejo na vejicah do naslednje pozne jeseni ali zime. Zato je rjavenje smrekovih iglic, ki jo opazimo letos, navadno posledica lanskih poškodb. Bolezen prepoznamo po značilnih črnih okroglastih piknidijih, velikosti 100$180 \mu \mathrm{m}$, ki množično izraščajo skozi listne reže (slika 7). V piknidijih nastajajo ovalni, brezbarvni konidiji, velikosti 13-19 × 6-9 $\mu \mathrm{m}$ (slika 8).

\section{Zaključek}

Poškodbe smreke zaradi smrekovega zavijača so bile v času od oktobra do decembra 2016 opažene na več lokacijah po Sloveniji. V literaturi ni podatkov, da bi se namnožitev tega škodljivca na območju Slovenije pojavila v tako velikem obsegu že kdaj prej. Po podatkih iz literature do namnožitev smrekovega zavijača prihaja na območjih, kjer so tla revna s hranili, preskrbljenost gostiteljskih rastlin z vodo pa je slaba, zato takšna območja predstavljajo večje tveganje. Glede na biologijo in pojavljanje vrste na drugih območjih po Evropi pričakujemo, da bo namnožitev kratkotrajna in ne bo povzročila negativnih posledic $\mathrm{v}$ gozdnih sestojih.

Glede na to, da smrekov zavijač ne povzroča škode v sestoju, se ukrepi za zatiranje tega škodljivca ne izva- jajo. Je pa v primeru obsežnih namnožitev potrebno vedeti, da prizadeta drevesa zaradi poškodb oslabijo in so bolj dovzetna za napade drugih škodljivih organizmov. Ker namnožitev smrekovega zavijača na nekaterih območjih sovpada z namnožitvijo smrekovih lubadarjev, predvsem osmerozobega smrekovega lubadarja (Ips typographus Linnaeus, 1758), je na teh območjih priporočljivo povečati aktivnosti odkrivanja lubadark in doslednega izvajanja predpisanih ukrepov $\mathrm{v}$ primeru pojava novih žarišč smrekovih lubadarjev.

\section{Zahvala}

Avtorji se zahvaljujemo prof. dr. Dušanu Jurcu in Mariji Kolšek za pregled besedila in konstruktivne pripombe ter vsem gozdarjem, ki so vestno spremljali stanje $\mathrm{v}$ svojih revirjih in sproti obveščali o pojavu poškodb.

\section{Viri}

Eurasian Tortricidae - Arthropods of Economic Importance. Zoological Museum, University of Amsterdam. http://wbd.etibioinformatics.nl/bis/tortricidae.php?menuentry=soorten\&id $=195$

Fauna Europaea. http://www.fauna-eu.org/node/66940

Jurc M. 2011. Gozdna zoologija. 3. natis, Univerzitetni učbenik. Univerza v Ljubljani, Biotehniška fakulteta, Oddelek za gozdarstvo in obnovljive gozdne vire: 348 str.

Kosibowicz M., Grodzki W., Jachym M. 2014. Local outbreak of the spruce needle tortricid Epinottia tedella Clerk (Lepidoptera, Tortricidae) in the Sudets in Poland. Beskydy, 7, 1: 29-38

Maček J. 2008. Gozdna fitopatologija. Ljubljana, Zavod za gozdove Slovenije, Zveza gozdarskih društev Slovenije - Gozdarska založba: 448 str.

Mutanen M., Kivela S.M., Vos R.A., Doorenweerd C., Ratnasingham S., Hausmann A., Huemer P., Dinca V., van Nieukerken E.J., LopezVaamonde C., Vila, R., Aarvik L., Decaens T., Efetov K.A., Hebert P.D., Johnsen A., Karsholt O., Pentinsaari M., Rougerie R., Segerer A., Tarmann G., Zahiri R., Godfray H.C. 2016. Species-Level Paraand Polyphyly in DNA Barcode Gene Trees: Strong Operational Bias in European Lepidoptera. Systematic Biology, 65, 6: 1024 1040

Titovšek J. 1994 Gradacije škodljivih gozdnih insektov v Sloveniji. Zbornik gozdarstva in lesarstva, 43: 31-76

Zúbrik M., Kunca A., Csóka G. 2013. Insects and Diseases Damaging Trees and Shrubs of Europe. Zúbrik M., Kunca A., Csóka G. (ur.) N.A.P Editions: 535 str.

${ }^{1}$ Gozdarski inštitut Slovenije, Oddelek za varstvo gozdov, Večna pot 2, 1000 Ljubljana; 2Zavod za gozdove Slovenije, OE Slovenj Gradec, Vorančev trg 1 , 2380 Slovenj Gradec; ${ }^{3 Z a v o d ~ z a ~ g o z d o v e ~ S l o v e n i j e, ~ O E ~ L j u b l j a n a, ~ T r z ̌ a s ̌ k a ~}$ cesta 2, 1000 Ljubljana; 'Zavod za gozdove Slovenije, OE Bled, Ljubljanska cesta 19, 4260 Bled; 5 Zavod za gozdove Slovenije, OE Nazarje, Savinjska cesta 4, 3331 Nazarje *andreja.kavcic@gozdis.si 


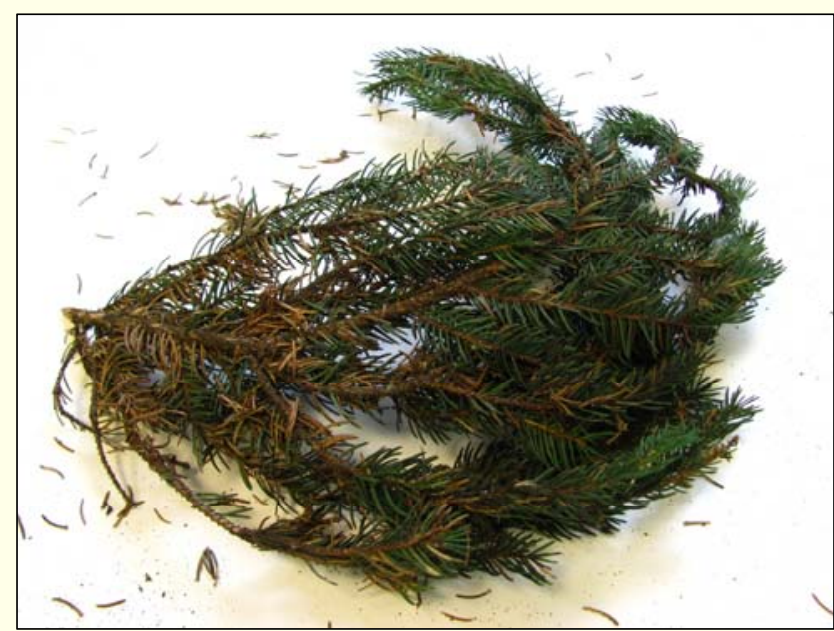

Slika 1: Simptomi na veji smreke, Picea abies - rjavenje, sušenje in odpadanje iglic. (Foto: A. Kavčič)

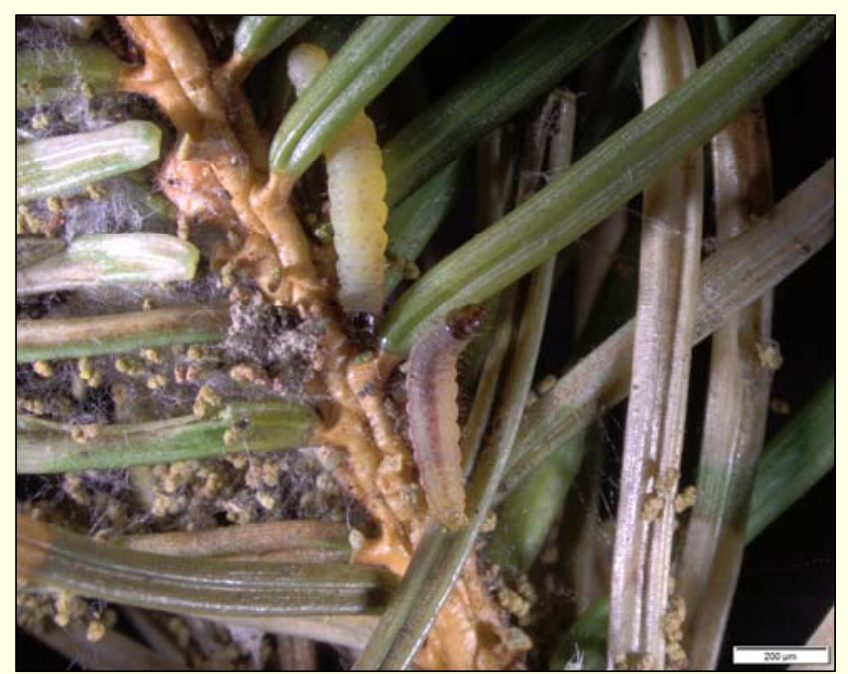

Slika 3: Gosenica metulja Epinotia tedella. (Foto: A. Kavčič)

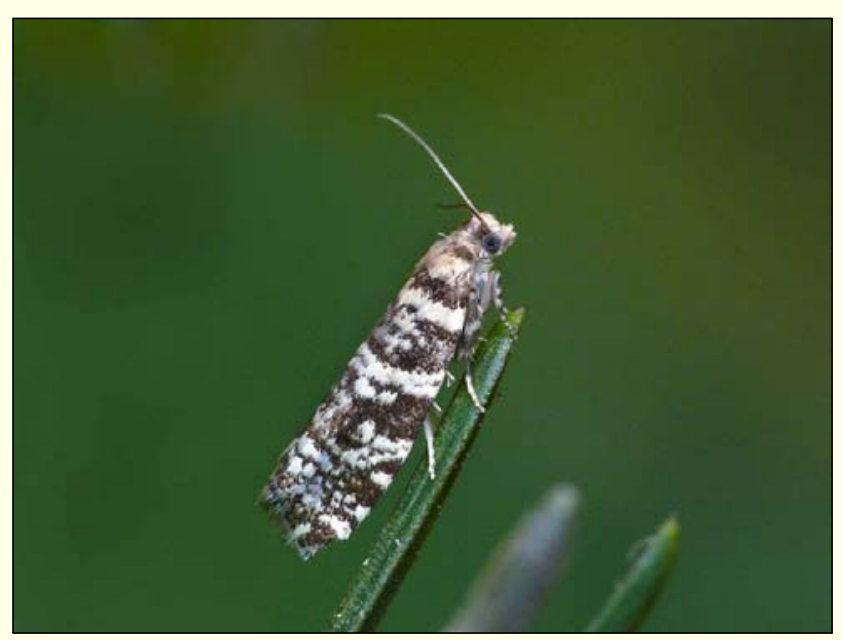

Slika 5: Odrasel osebek smrekovega zavijača. (Foto: Patrick Clement, www.ukmoths.org.uk)

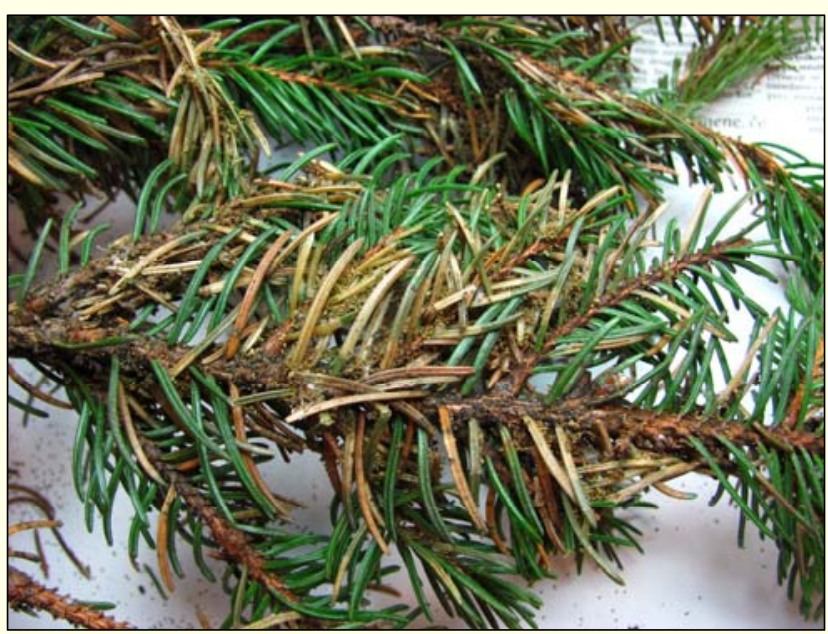

Slika 2: Spremembe na iglicah - rjavenje iglic, sprijemanje iglic, črvina med iglicami, na iglicah so prisotne ovalne odprtine. (Foto: A. Kavčič)

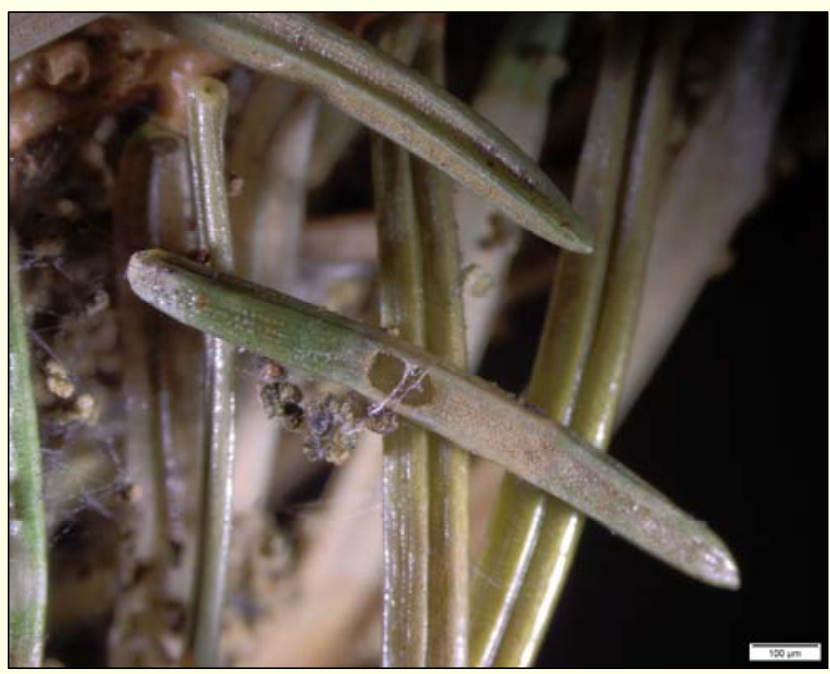

Slika 4: Poškodba na iglici - vhodna/izhodna odprtina. (Foto: A. Kavčič)

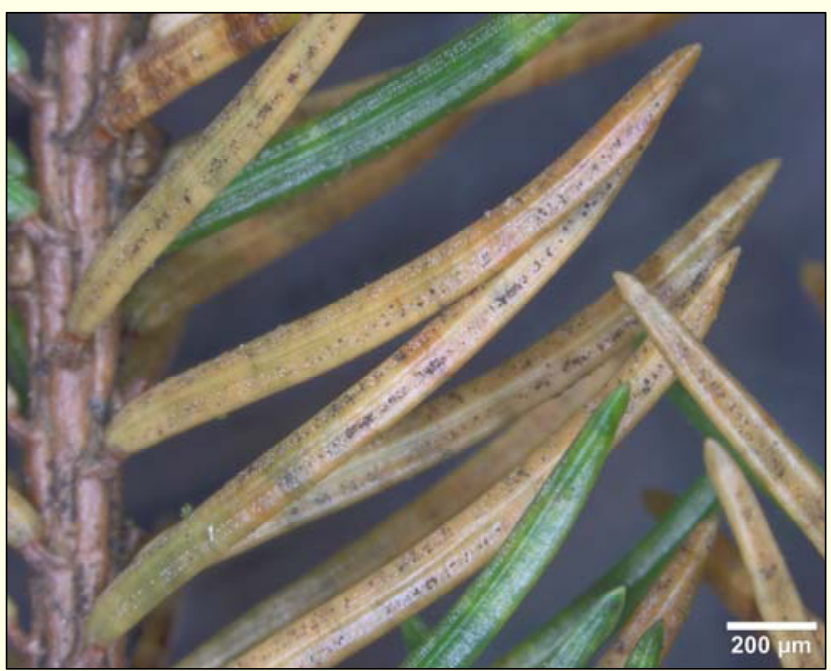

Slika 6: Rjavenje smrekovih iglic, ki ga je povzročila gliva Rhizosphaera pini (Foto: N. Ogris) 


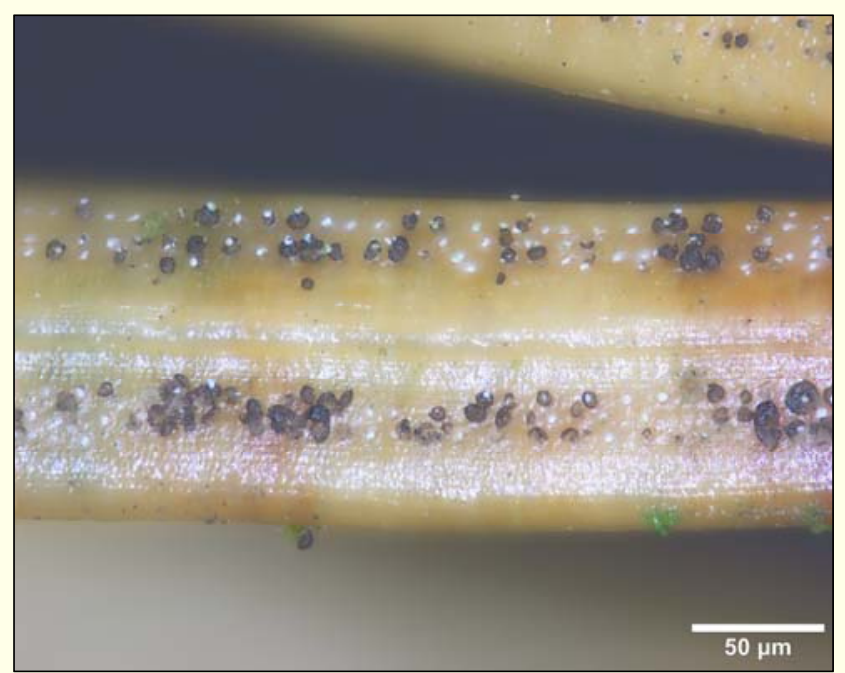

Slika 7: Iz listnih rež izraščajo črni okroglasti piknidiji glive Rhizosphaera pini (Foto: N. Ogris)

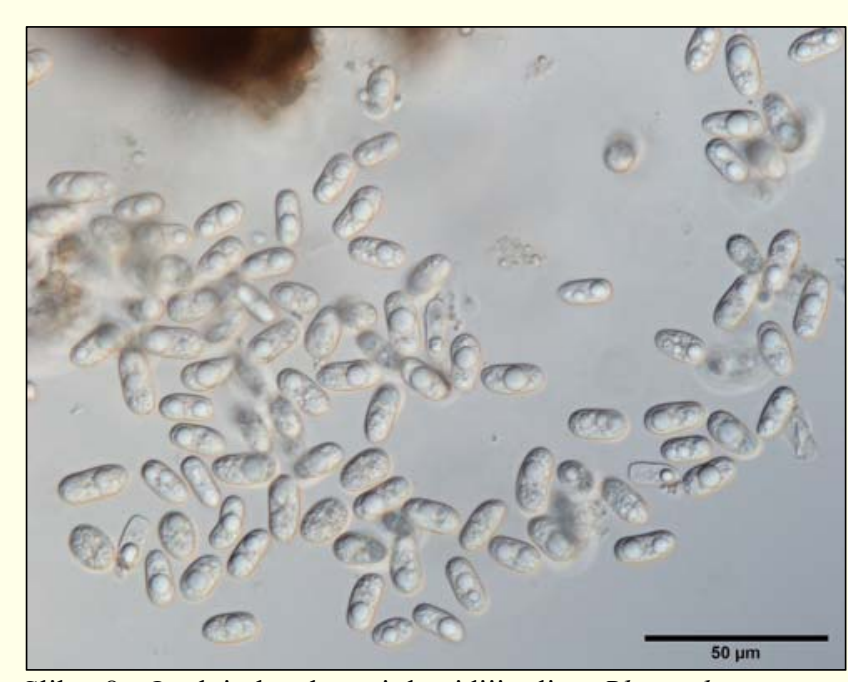

Slika 8: Ovalni, brezbarvni konidiji glive Rhizosphaera pini (Foto: N. Ogris) 